\title{
MEMBANGUN SIKAP TOLERANSI BAGI KAUM REMAJA
}

\author{
Raja Oloan Tumanggor \\ Editor: Arlends Chris
}

\section{Pengantar}

Kaum remaja sebagai generasi penerus kerap gampang dipengaruhi oleh lingkungannya untuk bersikap intoleran. Oleh sebab itu banyak kejadian intoleran di tengah masyarakat melibatkan kaum remaja. Salah satu unsur penting yang perlu diperhatikan untuk mengatasinya adalah dengan melakukan pelatihan untuk membangun dan meningkatkan sikap toleransi.

Dalam upaya membantu para remaja untuk membangun sikap toleransi dalam kehidupan seharihari, Dosen Fakultas Psikologi Universitas Tarumanagara (Untar) Jakarta, Dr. Raja Oloan Tumanggor, S.Ag. didampingi oleh seorang mahasiswa Jeaneta Monica, memfasilitasi pelatihan membangun sikap toleransi kepada 28 siswa-siswi SMA Katolik Tarakanita 2 Jakarta, pada 2 Desember 2020 lalu. Pelatihan yang berlangsung melalui Zoom itu merupakan undangan pihak sekolah kepada dosen Untar. Dalam sambutannya guru Bimbingan dan Konseling, Dra. Susiana Bertawati, yang mewakili Kepala Sekolah menuturkan bahwa kegiatan pelatihan ini diharapkan mampu memotivasi para siswa dalam membangun perilaku toleran di antara para siswa. "Kami mendukung sepenuhnya kerja sama antara Tarakanita dengan Untar dalam kegiatan pengembangan bagi para remaja di masa-masa yang akan datang," ungkap alumna Pendidikan BK Sanatha Dharma Yogyakarta ini.

\section{Pembahasan}

Pada bagian awal pemaparan ditampilkan beberapa fenomena intoleransi yang terjadi di Indonesia. Dari fenomena ini para siswa diajak merefleksikan apa itu toleransi. Toleransi merupakan sikap mau memberikan kebebasan dan penghargaan bagi orang yang berbeda dengan diri sendiri. Toleransi mencakup toleransi yang bersifat sosial dan bersifat pribadi. Toleransi sosial diperlukan dalam interaksi sosial dengan lingkungannya, sementara toleransi pribadi digunakan untuk menghadapi 
tekanan peristiwa hidup yang dialami seseorang. Keduanya diperlukan dalam hidup seseorang, sehingga dapat menumbuhkan sikap toleransi sedini mungkin.

Sependapat dengan Wahyudi (2017), sekolah memiliki peran besar dalam mengembangkan pendidikan karakter toleransi yang multikultural, yang dapat menumbuhkan sikap menghargai keberagaman. Pendidikan merupakan tempat tumbuhnya rasa saling menghargai perbedaan. Guru dan pendidik menjadi ujung tombak dalam menanamkan bibit toleransi bagi para anak didik dan guru menjadi teladan bagi mereka. Dengan membangun sikap toleran individu akan tidak cepat menunjukkan perasaan negatifnya terhadap orang lain yang tidak disenangi, melainkan berusaha menerima hal tersebut sebagai suatu yang pantas dihargai.

Selain itu toleransi juga merupakan keterampilan dan pemahaman yang diperlukan oleh setiap individu untuk dapat bertahan dalam dunia yang penuh dengan keberagaman. Anak remaja belajar bersikap toleran atau tidak toleran mulai dari lingkungan rumah, sekolah dan lingkungannya. Maka, toleransi hanya bisa dikembangkan dengan cara meningkatkan pemahaman tentang diri sendiri dan pemahaman terhadap orang lain.

Dalam bagian pemaparan berikutnya diberikan beberapa contoh sikap toleransi seperti menghargai perbedaan antara pemeluk agama, membiarkan orang lain menghayati kepercayaannya, saling menolong demi kemanusiaan tanpa memandang latar belakang suku, agama dan rasnya. Ada bermacam-macam jenis toleransi, seperti toleransi budaya, agama dan politik. Dalam skala yang lebih kecil dikenal juga toleransi di sekolah. Persoalan ini menjadi sangat relevan bagi para siswa yang dalam pergaulan sehari-hari berhadapan dengan teman yang beraneka ragam agama, suku dan keyakinannya.

Untuk mendalami materi, para peserta diajak untuk merefleksikan materi dengan memberikan beberapa pertanyaan panduan, seperti: apa pengertian toleransi bagimu, bagaimana cara mewujudkan toleransi di dalam keluarga, sekolah dan masyarakat; dari tiga macam toleransi agama, budaya dan politik, yang mana yang paling sulit diwujudkan? Bagaimana bentuk toleransi kamu lakukan terhadap temanmu?

Para remaja umumnya memiliki konsep yang memadai mengenai toleransi, misalnya menghargai perbedaan, menghormati, memaklumi dan memahami orang lain. Cara mewujudkan toleransi itu 
dalam keluarga juga mengandung unsur penghargaan, menghormati, menjalin komunikasi, ada keterbukaan, ada pengertian satu sama lain, kesabaran. Untuk lingkungan sekolah para remaja melakukan toleransi melalui sikap penghargaan dan penghormatan, tapi juga saling menyapa, mau bertanggung jawab terhadap sesama, mampu memahami orang lain dari perspektif mereka.

Menurut para remaja toleransi agama merupakan tugas paling berat dibandingkan dengan toleransi budaya dan politik, karena konsep dan keyakinan orang terhadap agama sangat spesifik dan cenderung fanatik. Selain itu toleransi agama menjadi lebih sulit diwujudkan karena orang masih kurang menghargai perbedaan dalam mengungkapkan keyakinannya. Berhadapan dengan teman sebayanya para remaja mengungkapkan sikap toleransinya melalui dukungan, menghormati pendapat teman, mau berkomunikasi dengan teman dari aneka suku dan budaya.

\section{Penutup}

Melalui pelatihan ini para remaja di SMA Tarakanita memperoleh gambaran fenomena intoleransi di Indonesia dan bertolak dari situasi itu mampu memahami makna esensial dari toleransi dan upaya apa yang dilakukan untuk membangun sikap toleransi yang dimulai dari kelompok kecil di dalam keluarga, sekolah dan masyarakat. Kegiatan seperti ini menjadi kesempatan yang baik bagi para dosen Untar untuk mengaplikasikan kompetensinya bagi masyarakat di lingkungan dunia pendidikan menengah. Para peserta mengapresiasi kegiatan ini dan berharap dapat dilanjutkan lagi di masa mendatang dalam bentuk workshop atau seminar lanjutan untuk mendiskusikan masalah aktual di dalam masyarakat menyangkut hidup toleransi. 